\title{
THE USES OF HOMER IN PLATO'S PHILEBUS
}

\author{
BERNAT TORRES \\ Universitat Internacional de Catalunya \\ btorres@uic.edu
}

\begin{abstract}
The paper presents a study on the presence of Homer in Plato's Philebus. After a brief summary of the dialogue and after indicating a couple of implicit references to Homer to be found in the Platonic text (like the figure of Aphrodite and the image of the journey of Ulysses), the work focuses on analysing the two single explicit appearances of Homer in Plato's Philebus. The first one in Philebus 47e, corresponding to the 18th book of the Iliad (108-109); the second one in Philebus 62d corresponding to the fourth book of the Iliad (450-456). The paper analyses these references in detail, examining Plato's use of the Homeric poems and analysing their significance, often hidden, in the dialogue as a whole. The analysis also shows the importance of the equivalences between Homer and Plato, that is, the similar or dissimilar treatment that they make of some important issues, like the description of human emotions, the confrontation between gods and men or the search for truth.
\end{abstract}

KEYWORDS: Plato, Homer, Socrates, Philebus, Odyssey, Iliad

ELS USOS D’HOMER AL FILEB DE PLATÓ

RESUM

L'escrit presenta un estudi de la presència d'Homer en el Fileb de Plató. Després d'un breu resum del diàleg i d'indicar un parell de referències implícites a Homer que es troben en el text platònic (com la figura d'Afrodita i la imatge del viatge d'Ulisses), el treball se centra en analitzar les dues aparicions explícites d'Homer en el diàleg, les quals remeten a la Ilíada. La primera es troba a Fileb 47e i ens remet al llibre 18 de la Ilíada (108-109); la segona es troba a Fileb 62d i ens remet al llibre 4 de la Ilíada (450-456). El treball analitza aquestes referències de forma detallada, observant l'ús que fa Plató dels poemes homèrics i analitzant la significació, sovint oculta, que una lectura atenta de les referències aporta a la comprensió del text platònic $i$ també al joc d'equivalències entre ambdós autors antics, és a dir, als llocs comuns entre la manera de tractar certs problemes, com la relació entre homes i déus, les emocions o la recerca de la veritat.

PARAULES CLAU: Plató, Homer, Sòcrates, Fileb, Odissea, Ilíada

In Plato's Philebus, Socrates is presenting to the reader a reflection about the best possible life; the dialogue, in its description of human nature, delves into the manifold of experiences of pleasure and pain and elevates toward the contemplation of reason as the source of order both in human life and in the cosmos. As human beings we are in the in-between, in the $\mu \varepsilon \tau \alpha \xi \dot{v}$, we live between a desired and never reached fulfillment and an immediate experience of emptiness and lack; we are always impelled to decide, as Socrates makes perfectly clear in the conclusive page of the dialogue, between the authority of

Data de recepció: 19/III/2016

Data d'acceptació: 25/VI/2016 
the beast and that of the philosophical muse that dwells in us (Philebus, 67b1-6). In the long journey of his research, Socrates will try to find, like a new Odysseus, his way back home, the dwelling place of the best life and the good, but despite all the efforts, he will not be able to reach his goal. At the same time, he will need to confront his arguments with two worshippers of the goddess Aphrodite, Philebus and Protarchus, who believe that pleasure is the best thing and will fight for its victory in the battlefield of the dialogue. In the construction of the conversation, Plato will remind us of the relevance of the Homeric imagery to describe, not the beautiful images of the hoped-for good and the best possible life (elements that are important parts of the argument), but the anger of the godly warrior Achilles avenging his friend Patroclus or the bloody war between the Greeks and the Trojans, a war originated and secretly organized by the gods. The Platonic' uses of Homer in the Philebus recall the violent and complex character of some aspects of human nature and recall the difficulties for the establishment of a friendly dialogue about important questions.

In most of the commentaries and academic presentations of the Platonic dialogues the Homeric imagery present in them is noticed, but often left unattended or unexplained. ${ }^{1}$ Our intention in the following lines will be to show that a careful examination of these images can enrich both the general interpretation of the Platonic text itself and shed at the same time some light on the sequence of events and experiences that both Homer and Plato shared.2 After a brief summary of the dialogue we will in the first section comment on a couple of general equivalences between the Homeric world and Plato's Philebus

${ }^{1}$ We can give testimony of this fact concerning the commentaries of Plato's Philebus, the dialogue to which we devoted our $\mathrm{PhD}$, where both the implicit and explicit references to Homer are often left unexplained and unexplored. So what we present here is as well a contribution to the understanding of Plato's Philebus. The most extensive work devoted to the presence of Homer in Plato's dialogue is the one of Labarbe (1987), the limitation of his work being that it offers only the references and a short philological explanation. There are in Plato around 150 direct references to the work of Homer, in Plato Philebus we find, as we have said, two of them.

${ }^{2}$ In this second sense, the exercise that we are presenting here can be understood as a search for equivalences of experience and symbolization between Plato and Homer and. As the work of Z. Planinc shows, the field of study that examines Plato's use and understanding of his tradition is familiar to the academics but "relatively unexplored"; Planinc considers that "there's a wealth of equivalent symbolizations of equivalent experiences in Greek literature before Plato; I assume that Plato's awareness and understanding of the phenomenon is broadly comparable to Voegelin's; I'm certain that Plato wrote the dialogues to reflect his understanding of this tradition; and I am also certain that the several versions of what I have been calling "reading the dialogues Biblically" are blind to it. The field of study is wide and rich and, despite the familiarity of the texts, relatively unexplored. The only obstacles preventing discovery of its treasures are the self-imposed limitations that can be overcome by following Nietzsche's simple rule: Do not read with the theologians' instinct" (Planinc 2007). See also Planinc (2008; 2004; 2003) and for the reference to Eric Voegelin see Voegelin (2000). 
and, after that, in the second and third sections, we will explore the two explicit references to Homer that Plato made in the dialogue: one in 47e (Iliad, 18, 108109) and the other in 62d (Iliad, 4, 450-56).

Plato's Philebus deals with the question of the happiest life, his main objective being to search for a "state or disposition of the soul that can render life happy for all human beings" (Philebus, 11d3-4). ${ }^{3}$ During his research, Socrates will be accompanied by the young and inexperienced Protarchus and his silent friend Philebus ('the lover of youth'); two apparently fictitious characters that represent a more or less extreme form of hedonism present in the city of Athens. ${ }^{4}$ Both seem to worship the goddess Aphrodite (Philebus, 12a4-c7) and this fact is connected with the idea that pleasure is identical with good and that the best possible life is a life of unlimited pleasure. In the long journey of the conversation, Socrates will need to prove that all these equations are false: that pleasure and Aphrodite must be conceptually detached and, moreover, that pleasure is not identical with the good although being part of the best possible life. Socrates will be mainly talking with Protarchus, who is willing to listen to him more that Philebus, who peacefully rests without being disturbed (Philebus, 15c9).

Both Philebus and Protarchus defend the view that for any living creature

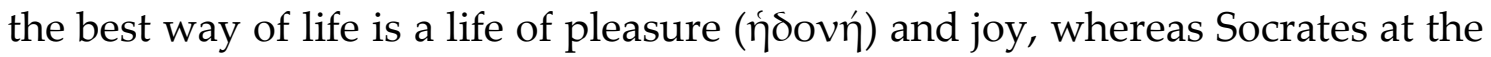
beginning of the dialogue defends the view that for any human being "to be thoughtful, to think, to remember, and, what's akin to them, right opinion and true calculation, prove to be better and preferable to pleasure" (Philebus, 11b6-

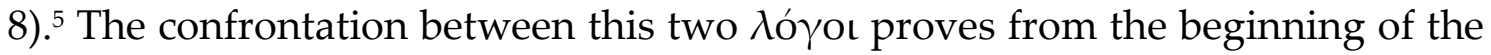
dialogue to be ineffective and that is why Socrates introduces a third possibility,

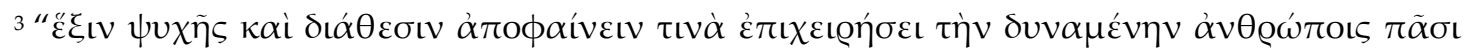

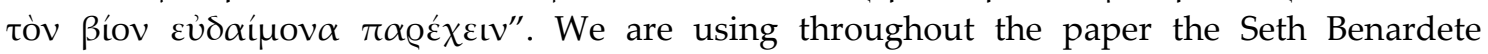
translation (Benardete 1993). For the Greek source we are using Burnet (1903), an edition available in the Perseus Digital Library.

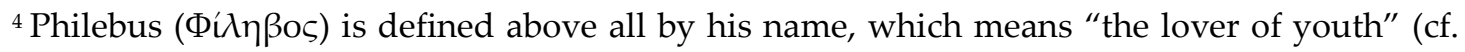
16b, 46b, 53d), which probably has to do with the pleasures deriving from the life of the young and their beauty; he is the original defender of a life of pure pleasure which will be transmitted to Protarchus. It has been suggested that Philebus may represent Eudoxus in this dialogue (Robin 1950) (Gosling 1975). See also Schofield (1971), Bringmann (1972) and Tarrant (2008) for the discussion around the enemies of Philebus (cf. 44b-51a) and the more or less clear reference

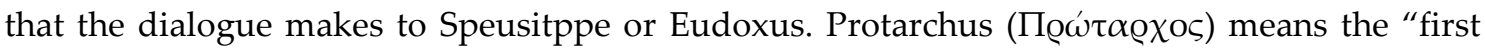
principle" or the "first beginning"; we know that he is the son of Callias (cf. 19b, 36d); he calls himself a disciple of Gorgias (cf. 57e), and he is a follower of Philebus and probably younger than him (cf. 16b3). Socrates is older than Philebus and Protarchus, and manifests a strange combination between the will to guide the reflection of the young Protarchus and that of

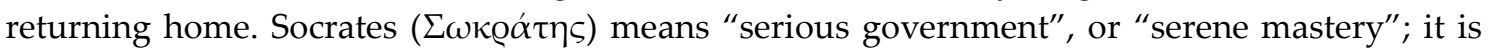
he who initially proposes the life of reflection as the best possible life, and he also describes the greatest pleasure as pleasure pure of pain (cf. 51a-52c).

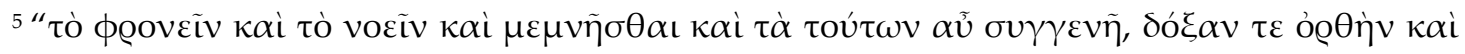

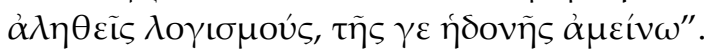


a third $\lambda$ ó mixture of pleasure and reason (Philebus, 22a-b; cf. 27d1-2). ${ }^{6}$ The fact that both Socrates and Protarchus share the possibility of this third option, a possibility

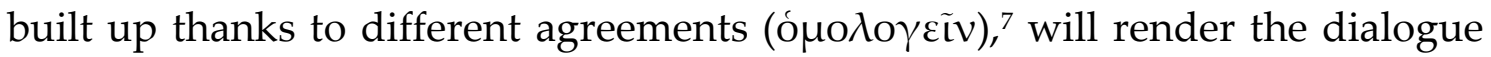
possible and effective because it will in fact allow discussion not focused on the victory of any of the opponents (that would be an eristic discussion), but on the

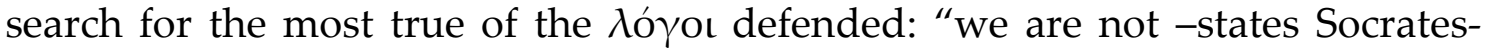

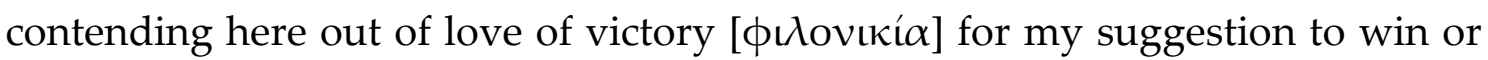

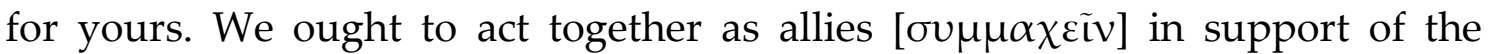
truest one" (Philebus, 14b3-6). The possible alliance ( $0 u \mu \mu \alpha \chi \varepsilon \tilde{\imath} v)$ between two initially confronted positions represents the searching for truth as a shared goal that tends to eliminate confrontations and enmities and allows a proper dialectical approach to the questions treated; an approach that is opposed to

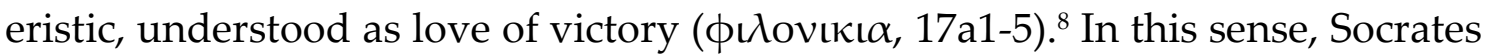
will insist that he is not one of Philebus' enemies or an enemy of hedonism, but a good friend of those who search for the truth in proper dialogue.

The construction of this third possibility, sustained on the common ground of a more or less stable alliance between Socrates and Protarchus, can very well explain the structure of the argumentative sequence of the dialogue as a whole. A sequence that can be divided into six sections and that will help us in locating the Homeric imagery in the dialogue as a whole. Firstly, a section where the dialectical method is presented as a way to deal with unities or concepts like reason, pleasure or the mixture of them (Philebus, 12c-20c). Secondly, a section where the notion of Good is examined as the model for the best human life understood as a mixture of pleasure and reason, defeating in this sense the two initial candidates, reason and pleasure (Philebus, 20b-23b). The third section, in a new attempt to make the dialogue possible between Socrates and Protarchus, moves to a description of the structure of cosmic reality, showing how this structure is bound to the structure of human life and the elements that constitute it (pleasure, reason and the mixture of the two); in this section cosmic reality is described as constituted by four elements: the unlimited (represented in our life by pleasure), ${ }^{9}$ the limit or the limitation, the

\footnotetext{
${ }^{6}$ See the final production of the mixture at $61 b-64 b$.

7 The presence of agreements is an essential element to understand a platonic dialogue. See Philebus 11c9; 11d-12a5; 14c and ff.; 20c and ff.

${ }^{8}$ Observe, for example, Socrates' response to the exigencies of Philebus: "Nor is your reason the good, Socrates, and the same complaint applies to us", where Socrates replies: "It may apply to my reason, Philebus, but certainly not to the true, the divine reason, I should think" (Philebus, 22c2-5). The true and divine reason, difficult as it may be to reach it, seems to be a good basis for a friendly conversation.

${ }^{9}$ It is important to note that although pleasure in itself is part of the category of the unlimited, this element can be also seen, from the point of view of its origin, as part of the genus of the
} 
mixture between them (represented in our life by the best possible mixture of pleasure and reason) and, finally, the cause of this mixture (represented in our life by reason as a source of order and limitation) (Philebus, 23c-31a). After that, Socrates initiates in the fourth section, the longest of the dialogue, a very extensive and complete analysis of the nature of pleasure, showing its origin in the human body and the different forms it takes to find at the end the most pure forms of pleasure (Philebus, 31b-55c). Then, we find a short section examining the nature of reason, its different kinds and determining as well the most pure or exact forms of science (Philebus, 55c-59c). After that, in the last section of the dialogue, Socrates will go on to produces in the speech the best possible mixture, taking the most pure elements of pleasure and most of the elements of reason to create a beautiful, measured and true mixture, a mixture that should represent the best possible human life (Philebus, 59d-66d). As we will see, the explicit quotes of Homer are both to be found at the end of the dialogue, the first one in the fourth section devoted to analyze the nature of pleasure; and the second one in the section where the mixture of pleasure and reason is produced in the speech. However, before analyzing them, let us comment on more general and implicit equivalences between Plato and Homer: the first one concerning the general subject of the dialogue, that is, the choice for a certain way of life represented by the divinity Aphrodite; the second one concerning the Socratic journey in the dialogue and its possible equivalence with Odysseus' journey.

\section{APHRODITE'S CHOICE AND THE WAY BACK HOME OF THE HERO}

At the beginning of the dialogue, Philebus acknowledges that he is a follower and a worshiper of a divinity that seems to be Aphrodite, the goddess of love, pleasure and procreation. ${ }^{10} \mathrm{He}$ recalls this divinity to witness his withdrawal from the conversation: "As a matter of fact, I wash my hands of it entirely and call to witness now the goddess herself" (Philebus, 12b1-2). This divinity -as we stated before- will be identified by Philebus and Protarchus with pleasure and with the good itself (Philebus, 13b8-c3); an identification that Socrates will need to prove to be false. His prove will begin with a clear expression of his respect in front of the names of the gods:

mixture or the common in so far as pleasure always arises together or combined with pain (Philebus, 31c2-4).

${ }^{10}$ See Hesiod, Theogony $176 \mathrm{ff} ;$ Works and Days $60 \mathrm{ff} ; 520 \mathrm{ff}$. For the presence of Aphrodite in Homer see Iliad 5. $429 \mathrm{ff} ; 5.349 \mathrm{ff} ; 5.422 \mathrm{ff} ; 3.389 \mathrm{ff} ; 14.187 \mathrm{ff}$. As it is well-know, in the Platonic dialogues a distinction is made between two different kinds of eros and two Aphrodites; one of them is 'popular', the other, ourania, carries all the aristocratic overtones; only the latter one is to be defended and praised by Pausanias in his speech in Plato's Symposium (180d4-5). 
[my dread] in the face of the names of the gods -says Socrates- is never on a human level but lies beyond the greatest fear. So now in the case of Aphrodite, in whatever way it's dear to her, that's the way I address her; but as for pleasure I know it's a complex thing, and in beginning from it, just as I said, we must examine and reflect on what nature it has (Philebus, 12c1-5).

Socrates' intention before Philebus and Protarchus at the very beginning of the dialogue will be to deprive pleasure of its godly aura (of its identification with Aphrodite) in order to examine it as a unity that arises primarily as a human experience. In this sense, one of the main objectives of Socrates in the first part of the dialogue will be the de-mythologizing or de-divinizing of pleasure. That does not mean at all that in his research pleasure cannot be shown as an element connected with some transcendent order; in fact, at the end of his analysis, pleasure will be identified with $\alpha \pi \varepsilon$ í $\omega v$, a formless and always changing reality, essential element of the cosmic order (cf. Philebus, 31a6-9; 53c ff.). ${ }^{11}$ As it often happens, the Platonic examination connects -in the dramatic scene of the dialogue- the human with the divine and the cosmic in order to reach a proper comprehension of the questions treated. Socrates' examination of pleasure will be followed and in some sense shared by Protarchus, but Philebus will rest in peace and remain almost silent all the time. He will remain all along the dialogue a pious follower of Aphrodite: for him pleasure must be identified with this divinity and also with the good and with the unlimited; "for unless it were in fact by nature unlimited in point and manifold and the more, pleasure would not otherwise be totally good" (Philebus, 27e7-10). Philebus has made a choice, a choice for a life of pleasure understood as a simple and plain experience (as a more without a less, as joy without pain), ${ }^{12}$ a life in the unlimited under the auspices of Aphrodite. The very possibility of the dialogue is built upon the fact that Protarchus has not yet made his definitive choice.

The relevance of this fact and the presence of the divinity in it is what allow us to trace an important indirect equivalence between Homer and Plato. This is so because the divinity of Aphrodite is presented both in the dialogue and the Homeric poem (and of course in other sources of the Greek tradition) as the origin of a confrontation, a confrontation that has to do in both cases with a choice. As M. Dixsaut points out, this choice in the dialogue may be a reminder of the choice or the judgment of Paris, a choice that favored Aphrodite in front

11 Pleasure understood as $\alpha \pi \varepsilon$ ć $\omega v$ offers to the reader a new example to understand the inbetween character of our existence, because $\alpha \pi \varepsilon i ́ \rho \omega \nu$ is both an element of the cosmic reality and of the human soul. In locating pleasure in its right place in reality, Socrates makes superfluous and irrelevant the identification between pleasure and the divinity Aphrodite.

${ }^{12}$ As the dialogue will show, Philebus' understanding of the unlimited character of pleasure is wrong in the sense that it does not take into account the connection between pleasure and pain, that is, the mixed nature of pleasure. In doing this, Philebus shows his ignorance concerning his own self-representation and image. 
of Hera and Athena and that in the Homeric tale brought the Athenians to the dreadful war against Troy (Iliad, 24, 25-30). ${ }^{13}$ Indeed, also in the dialogue Aphrodite represents the origin of the conflict between the interlocutors. All along his journey, Socrates will need to persuade and in some sense convert Protarchus in order to show him that the best life is not the one that Philebus has chosen, devoted to the unlimited pleasures of Aphrodite, but a life devoted to a moderate joyful existence that acknowledges its unlimited character in the right way. ${ }^{14}$

Another equivalence can be found concerning the image of the journey that the dialogue describes and, what is more important, the inability or impossibility of Socrates to return home. When Socrates explains the methodology that he and Protarchus are going to follow in order to reach the fixed goal (i.e. the production in the speech of the best possible mixture between pleasure and reason of which the happiest life consists), he talks about the «the finer way» ( $\alpha \alpha \lambda \lambda i ́ \omega v$ ódòs; cf. Philebus, 16b6), the so called dialectical method. This method or way, in a similar sense as it happens in other dialogues like the Republic, is more than an analytical method of dividing and classifying; it is a way or a journey in which different difficulties and dangers are presented. There is no way, no possible method, without the difficulties that accompany it, that means that there is no method without perplexity:

there is not -states Socrates- nor would there ever be, a more beautiful way than the one of which I am always a lover, although it has often before now escaped me and left me deserted, pathless, and perplexed [ärọos] (Philebus, 16b6-9).

In fact, the different perplexities can very well explain the sequence of the dialogue. Moreover, to complete this image and to connect it with the Homeric journey of Odysseus, the dialogue shows a Socrates that is all through his journey willing to go back home ${ }^{15}$ and that, at the end, he will be unable to reach his goal. In this case not because of a prophecy, but because Plato wanted to remind us of the unlimited nature of pleasure, the unlimited nature of Protarchus' desire for discourses and, in a broader sense, the impossibility of reaching the good in human life. At the end of our exposition, we will be able to clarify more accurately this impossibility. Now, let us focus on the two explicit references to the Homeric poem that we find in the dialogue and, through them, let us try to better clarify this Socratic journey keeping always in mind its connection with the one Odysseus is also trying to fulfill.

\footnotetext{
${ }^{13}$ Cf. Dixsaut (1999: xii); see also Ovid (Heroides 16, 71 ff., 149-152 and 5, 35 ff.).

${ }^{14}$ Dorothea Frede goes as far as to think that the main objective of the dialogue is what she calls the conversion of Protarchus (Frede 1993: 1xv).

${ }^{15}$ See Philebus 19e1, 23b1-2, 50d2-10, $62 \mathrm{~b} 9$.
} 


\section{ACHILLES' WRATH AND THE UNHIDDEN MIXTURES OF PLEASURE AND PAIN}

The first explicit references to be found in the dialogue is in Philebus 47e, in the long analysis of the nature of pleasure (cf. 31b-55c); and the second one in Philebus $62 \mathrm{~d}$, in the next to last section of the dialogue, where the final mixture between pleasure and reason is produced in the speech (cf. 59d-66d). Both references bring us to the Iliad, the first to book 18, where Achilles expresses his wrath when he knows that his friend Patroclus has died at the hands of Hector (Iliad, 18, 108-109); the second one to book 4, where a description of a dreadful battle between the Greeks and the Trojans is given (Iliad, 4, 450-56).

The first reference is found in the longest section of the dialogue, where the nature of pleasure is analyzed and where the intention is also -as we have said before- to find the purest kinds of pleasure that are going to be allowed in the final mixture of which the best human life consists. Before commenting on the reference let us offer a short review of this long section of the dialogue, where Socrates will defend the thesis that -according to what has been explained in the cosmological part of the dialogue- "pleasure in itself is unlimited [ $\dot{\alpha} \pi \varepsilon \dot{\varrho} \omega v]$ and of the genus in and of itself that does not have and never will have a beginning, middle, or end" (Philebus, 31a6-9). The unlimited nature of pleasure (apart from being something connected to its cosmological origin as $\dot{\alpha} \pi \varepsilon(\hat{Q} \omega v)$ has to do with its interrelation with pain in human experience. This is so because in the experience of pleasure there is always a restoration of a state of harmony (identified with a state or process of fulfillment) bound with a destruction of this harmony (identified with a state or process of lack or emptiness where we feel pain). This process of destruction and restoration can be found in the body alone but it reveals its complexity when we observe it in the soul and, mainly, through the experience of

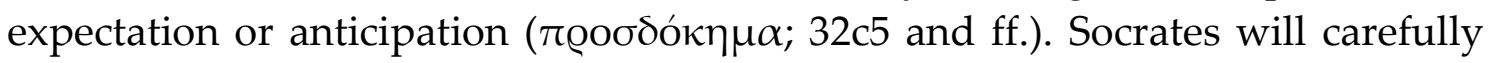
clarify the experience of expectation through a description of perception

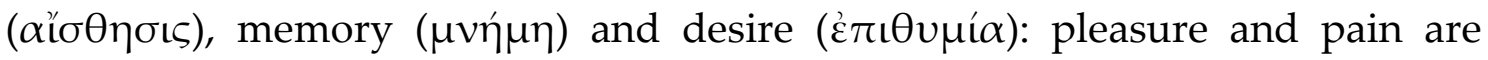
always bound together because we desire always the opposite of our present state, because "every living creature always strives towards the opposite of its own experience" (Philebus, 35c6-7; cf. 31c-36c). This description of the way anticipatory pleasure operates in us (which serves at the same time as a description of an essential element to comprehend human nature and experience) will be relevant to understand the Homeric representation of Achilles' wrath, where there is an actual feeling of pain mixed with a pleasant expectation of revenge.

These kinds of pleasure are considered by Socrates as false, not only because of their unlimited nature (their connection with pain make them confusing and difficult to determine), but also because of the presence of a judgment in any circumstance where we feel, or imagine that we feel, pleasure or pain; a judgment that can be true or false, just or unjust (cf. 36c-46b). To 


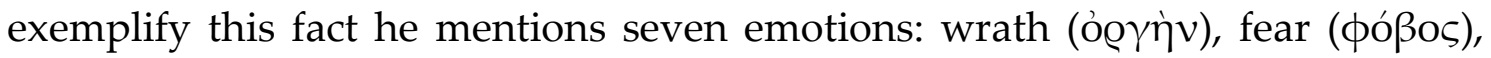

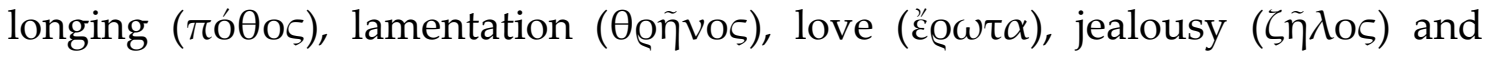
malevolence $\left(\phi \theta\right.$ óvos), ${ }^{16}$ and then proceeds by explaining two of them. In the first case using the Homeric reference to Achilles wrath; and in the second case an example taken from comedy, where an implicit reference to Aristophanes is made. In experiencing wrath or anger against our enemies (as it happens in the case of tragedies) or in laughing at the misfortunes of our friends (as it happens in the case of comedy), the pain or the pleasure felt (or the mixture between them) is not neutral, but implies, as we just mentioned, a true or false judgement. It is relevant to notice that the reference to the Homeric' poem is not explained by Socrates, mainly because Protarchus seems to understand it without problems. ${ }^{17}$ The image has nevertheless a density that Protarchus fails to notice and that we will develop in the following lines. On the other side, Protarchus will have many difficulties in understanding the example of comedy, where in laughing we feel a clear pleasure apparently devoid of pain. That is why Socrates will devote a quite long argument to clarify this hidden experience felt in comedies (cf. Philebus, $47 \mathrm{~d}-50 \mathrm{e}$ ). ${ }^{18}$ In any case, it is worth

${ }^{16}$ To understand all these mixtures it is relevant to see that in the Philebus, human soul is not described as a tripartite structure like in other Platonic dialogues, but through the fact that every emotion contains a portion of its opposite: each desire is a mixture of pleasure and pain because desire always implies the opposite of the present state. And this principle applies to all

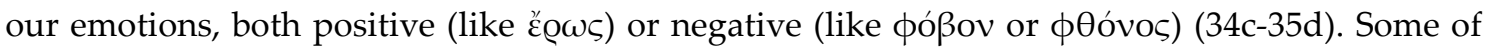
these emotions have been explained in different dialogues, like Ө0ர̃vos (Phaidon, 59a-b1) or Ěows (Symposium, 206d3-e1; Phaedrus, 251c5-252).

${ }^{17}$ Some scholars put forward that the reason Socrates is not explaining the experience of wrath in tragedies is because it has been already explained in other dialogues, like the Republic. In this dialogue, tragic poetry is described as a false $\mu$ í $\mu$ $\sigma \varsigma$ : "we shall say the imitative poet produces a bad regime in the soul of each private man by making phantoms that are very far removed from the truth and by gratifying the soul's foolish part, which doesn't distinguish big from little, but believes the same things are at one time big and at another little" (605b6-c3). In tragic poetry we praise as a good poet the man who most puts us in the state of being delighted because of the suffering of the hero; but when that happens to us, we find it shameful (605c10-d5). Various authors have used this reference from the Republic as a key element to understanding the argument of the Philebus concerning tragedy and comedy. However, we believe that in the case of the Philebus, the clarification on these issues is carried on from a different perspective, first of all because in the case of the Philebus no reference is made to the tripartition of the soul which is at the background of Socrates' argument in the Republic; and also because in the Philebus tragedy and comedy are not considered as sources of confusion or error, but as a way to offer a diagnosis of the different reactions internal to our soul that are found in them (Frede 1993: xlvlviii).

${ }_{18}$ Protarchus is apparently able to see the hidden pleasures behind the pains of tragedy, but will be unable to see the pains behind the pleasures of comedy. Indeed, when Socrates gives the example of comedies Protarchus fails to see the painful element, and, without a painful element, there is no mixture in comedies, but a rather simple and neutral pleasurable experience. "Since it is such an obscure matter-says Socrates to Protarchus- let us be all the more careful. For this will help us to recognize more easily when there is a mixture of pain and pleasure in other cases 
noticing that the falsehood of pleasures and pains in the tragic or the comic scene reveals not only the nature of pleasure but also its relevance to understanding human life in all its complexity, what Socrates calls "the entire tragedy and comedy of life" (50b2). ${ }^{19}$ In addition, this is so because, as we have said before, these experiences show that "every living creature always strives towards the opposite of its own experience" (Philebus, 35c6-7).

Let us now focus on the first example, the one where the Homeric quote appears. The description of the emotion of wrath or anger is made using a version from a fragment of the Iliad, where Achilles describes this emotion by saying "...that can embitter even the wise... but much sweeter than softglowing honey...". This experience, adds Socrates, is to be found in lamentations and longings and in the "tragic spectacle, when people weep at

as well" (Philebus, 48b4-8). It is obvious that comic situations and comical scenes are pleasurable, because we laugh at a situation or a person that we find to be ridiculous and this laughing is something obviously pleasant. The difficulty of Socrates' example is to see which the painful element is; and his answer is to be found in the concept of $\phi \theta$ óvos. The commentary of the example of comedy would bring us to talk about another equivalence also very relevant and maybe clearer, the one between the dialogue and the comedy of Aristophanes. That would be, nevertheless, the subject of another paper. Let's just say that the reason Socrates is presented as ridiculous in the Clouds, as a physician or cosmologist, is the same that makes him feel ridiculous in the scene of the Philebus, when he is dividing the reality into parts or kinds (cf. Philebus, 23d1-5). The unjust and hidden mixture of pleasure and pain to be found in comedies represents a critique of the Aristophanic way of treating Socrates, of dealing with his wisdom and ignorance and with his ridiculousness. Our main concern here is, nevertheless, the example of tragedy, the one that Protarchus seems to understand without difficulty because in it the mixture seems to be unhidden.

${ }^{19}$ Moreover, it's worth saying that the Socratic examples of tragedy and comedy focus the attention of the reader on the social or political dimension of human life. This is important at least for two different reasons in the context of this dialogue. The first one is that Plato's Philebus, despite dealing in some sense with a socially relevant discussions on pleasure and human happiness, does it without the arguments and the strategies of the political philosophy that we know from other dialogues. Benardete may be right (although in a quite hyperbolic manner) when he affirms that "Socrates, then has been put by Plato in the difficult position of arguing against pleasure without any of the weapons with which his discovery of political philosophy might have furnished him" (Benardete 1993: 90). The indirect political significance of the dialogue is nevertheless clear concerning the relevance of education (the education of the pleasure and the education of youth) and concerning the different discussions presented in the dialogue. Dorothea Frede affirms that one feature of the dialogue is the return of a more "democratic Socrates", a Socrates who is ready to design a best form of life that is acceptable to ordinary people (Frede 2010: 5). Francisco Lisi, in a similar sense, defences the centrality of the law in the argument of the dialogue (Lisi 2010: 178-187). See also Voegelin (2000). Secondly, the analysis of the mixture between pleasure and pain in the soul alone is, paradoxically, the one that brings us closer to an understanding of the political dimension of human life, a dimension where words like justice and injustice, false or true wisdom, friendship and enmity are relevant. Indeed, through this argument, Plato is showing us again the intimate connection between the human soul and the soul of the city; that which is written large in comedy and tragedy is written small in our souls, in the tragedy and comedy of our life (cf. Plato's Republic, 368d). 
the same time as they are rejoicing" (Philebus, 47e-48a). Notice that Socrates is not only describing the blending together of pleasure and pain from the point of view of the hero, but also from the point of view of the spectator of the tragedy, who is rejoicing and lamenting at the same time. Although we are not told which is the reason for our rejoicing as spectators, we can imagine that our pleasure comes from the fact that we are sure that we are not going to suffer the pain that we see in the scene (of course, the pain seems to be produced by the experience of seeing others suffering).${ }^{20}$ Nevertheless, as we have said, Socrates' image refers mainly to the experience of the hero, who is in quite a different situation to that of the spectator: Achilles lamenting is again clear (he feels pain because of the death of his friend), but the reason for his pleasure remains hidden and unclear. Some clarification may be found, as we have said, in the description of the experience of expectation or anticipation, the first kind of false pleasure described (Philebus, 39d-41b). In the face of an experience of a lack (felt as a pain) we desire the opposite of our present state and, in doing so, we can feel a pleasure in our expectation, a pleasure that can be true or false (just or unjust). In this sense, the pleasure derived from the expectation of Achilles could be a pleasure produced by an image of the horror of death and revenge, a pleasure produced by the expectation of his glorifying revenge, a pleasure that Protarchus seems to recognize immediately. The Socratic argument seems to indicate that Achilles judgement (the judgement implied in his experience where pleasure and pain are mixed together) is a false one, producing in this sense a false pleasure.

It is interesting to notice that when Socrates explains the way in which we can distinguish between true and false pleasures of expectation he states that pious and good men have true expectations, whereas bad and impious men have false expectations:

\footnotetext{
[A]re we to say, then, that the painting ${ }^{21}$, for those who are good, are set before them for the most part as true, because they are dear to the gods, but for the bad in turn it's very much the contrary? [...] The wicked, then, rejoice in false pleasures, but the good among human beings rejoice in true (Philebus, 40b1-c1).
}

${ }^{20}$ This seems to be confirmed by Aristotle' remark in his Rhetoric, where, using the same Homeric quote that Plato is using, he defines óorì "as a longing, accompanied by pain, for a real or apparent revenge for a real or apparent slight, affecting a man himself or one of his friends, when such a slight is undeserved [...] and because this individual has done, or was on the point of doing, something against him or one of his friends; and lastly, anger is always accompanied by a certain pleasure, due to the hope of revenge to come" (Aristotle, Rethoric, II 1 , 1378 a 31-33).

${ }^{21}$ By 'paintings' ( $\tau \dot{\alpha} \gamma \varepsilon \gamma \varrho \alpha \mu \mu \varepsilon ́ v \alpha$ ) Socrates means here the images that we have in our expectations, the image of myself being happy in the future would be a good example of these paintings or images. 
This argument comes now into play with the pleasures felt by Achilles. The Homeric hero is in fact loved by some gods and hated by others and his pleasures are not precisely true or good, but rather bad and false. ${ }^{22}$ The fact that Protarchus is not aware of this fact proves that he does not fully understand the example of tragedy.

To further grasp the relevance of the Socratic example, let us now turn our attention to its source in book 18 of the Iliad, at the moment where Achilles realizes that his beloved friend and comrade Patroclus died at the hands of Hector. Achilles is lamenting and raging over his failure to protect his friend and wishes to return to the battlefield with the sole aim of avenging him, even though the gods had warned that it would cost him his life. Now, if we observe the immediate context of the quote from the Iliad some interesting elements will arise:

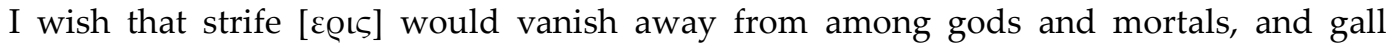

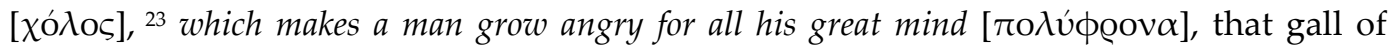
anger that swarms like smoke inside of a man's heart and becomes a thing sweeter to him by far than the dripping of honey. So it was here that the lord of men Agamemnon angered me. Still, we will let all this be a thing of the past, and for all our sorrow beat down by force the anger deeply within us. Now I shall go, to overtake that killer of a dear life, Hector; then I will accept my own death, at whatever time Zeus wishes to bring it about, and the other immortals [...] Now I must win excellent glory, and drive some one of the women of Troy, or some deep-girdled Dardanian woman, lifting up to her soft cheeks both hands to wipe away the close burst of tears in her lamentation, and learn that I stayed too long out of the fight. ${ }^{24}$

Many elements are remarkable in the Platonic use of the Homeric image. ${ }^{25}$ It shows, on the one hand, that Plato finds in the poetic expression of emotions

\footnotetext{
${ }^{22}$ As Benardete correctly states, "Achilles speech as a whole makes clear that the pleasure of anger consists in the vividness with which one depicts in advance the punishment one is certain will be inflicted on the wrongdoer. Socrates account of the difference between the just and the pious man and the wicked would have to be revised on the basis of what he implies" (Benardete 1993: 200).

${ }^{23}$ Note that the quotation used by Socrates is a slightly modified version of the original text,

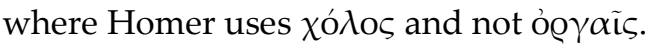

${ }^{24}$ Iliad, 18, 105-120. We are using throughout the paper Richard Lattimore translation, both of the Iliad and the Odyssey (Lattimore 1975; 1977). For the Greek source of the Iliad we are using the Oxford edition of 1920, and for the Odyssey the Cambridge-London edition of 1919, both available in the Perseus Digital Library. Italics are marking the correspondence with the Platonic quote, which has been, as we can see, shortened and slightly modified.

${ }^{25}$ One that we won't be able to develop in our text is a hidden peculiarity of the example of tragedy (a peculiarity which is explicit in the case of comedy), which is the relevance of friendship in it. The fact that without the presence of an offense made to a friend, wrath or anger wouldn't have taken place (in this case the one between Achilles and Patroclus). It is worth mentioning that the Homeric quote makes a clear distinction between Achilles' wrath against Agamemnon, where no friendship seems to be implied, and his wrath against Hector,
} 
used by Homer something useful for his argument and, on the other hand, it tells us something about different ways of understanding human nature, its emotions and its relation with the gods. The Socratic or Platonic way of explaining or showing human emotions becomes different here -although not radically different- from the one used by Homer. This is so because in the Homeric scene there seem to be no end or limit to the godly and the human will for revenge or hate, ${ }^{26}$ whereas the Platonic dialogue tries to show precisely the unlimited nature of human emotions, an unlimited nature that must be taken into account in the representation of the best possible life, a life constituted by pleasure and reason in its due measure. Plato, throughout the construction of the dialogue and the analysis of human nature shows us new possibilities of relating within the community and with the gods, rethinking and relocating the complexity of human emotions. ${ }^{27}$

It is worth noticing that both Achilles and Socrates seem to be willing to finish the disputes between men and god, but Plato's quotation in the dialogue -by omitting the presence of हैoı - doesn't reveal these elements for some

where it is precisely his friendship with Patroclus that explains his reaction, his wrath and his desire to return to war. It is because of his friendship with Patroclus that Achilles is feeling and expressing the wrath against Hector that Socrates has chosen as an example of the hidden mixture of pleasure and pain in the soul alone. To confirm this connection between the scene and friendship we can turn again to Aristotle's Rhetoric where we find exactly the same Homeric quote, in the moment where ọy real or apparent revenge for a real or apparent slight, affecting a man himself or one of his friends, when such a slight is undeserved" (Aristotle, Rethoric, II 1, 1378 a 31-32). See also Aristotle Topoi (IV 5, 125 b 32-34).

${ }_{26}$ "si tel est le cas, on pourrait alors affirmer que Platon s'oppose, sur ce point précis, au discurs de la tragédie qui pose, en effet, que seule la douleur pure impose le silence à l'envie (dans l'Agamemnon d'Eschuyle, on lit au vers 904 que l'envie se tait devant la souffrance) et que c'est par la douleur absolute que cesse la vengeance interminable" (Wersinger 2010: 335).

${ }_{27}$ There is another element that can enrich even more these equivalences, namely the reference to the great mind or the moderate man: "gall, which makes a man grow angry for all his

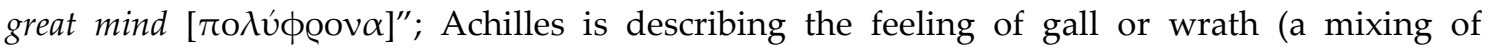
pleasure and pain that becomes mortal and tragic in the Homeric poem) of a very moderate man. Again, Protarchus doesn't seem to notice the presence of this important element, but the

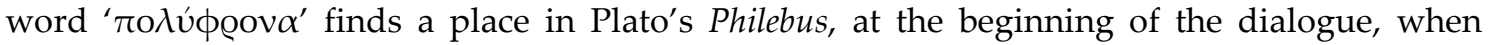
Socrates mentions different pleasures felt by different kinds of men, like in the intemperate (

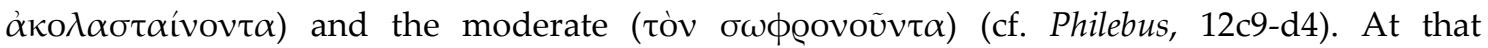
moment, Protarchus accepts that these pleasures arise in different circumstances, but that in themselves they are not contrary to one another but identical to each other. Making Protarchus understand the difference between the pleasures of the moderate and the immoderate man (showing the complexity of pleasure as a unity) will be one of the main objectives of the dialogue as a whole and that makes the presence of the moderate man an important element in the Platonic dialogue. Again, the Socratic or Platonic model of a moderate men is clearly connected with the Homeric image but they are also different and this difference is similar to the one found between Achilles' way of confronting difficulties and situations of conflict and the Socratic way of doing it. 
reason. Indeed, immediately before the Socratic quote, in the text of the Iliad Achilles mentions his will to finish the disputes (čıs) between men provoked by the gods: "I wish that strife would vanish away from among gods and mortals". Eristic, as we have said, is an important concept in Plato's Philebus, a concept opposed to dialectics as the proper way to search for the truth (Philebus, 17a2-4). In the context of the dialogue, eristics seems to represent precisely the way Protarchus is confronting the questions, a way that is represented by an understanding of pleasure as a godly reality (remember the presence of Aphrodite in the dialogue). Dialectics, on the contrary, represents the proper way of confronting problems, a way that respects the real situation of the human condition. This opposition, nevertheless, will disappear in the confrontation that the dialogue shows and, in this sense, the distance between the poet and the philosopher does not seem to be so big. This fact, the failure to locate dialectics as the purest possible wisdom, could explain the reason why Plato is not mentioning eristics in his Homeric quotation. Be that as it may, it seems relevant to notice that in the Platonic dialogue éoı impossible the conversation, whereas dialectics, presented in the dialogue as a gift from the gods to men, make it possible, as Socrates shows by trying courageously and tirelessly, together with others, to search for the truest (cf. Philebus, 16c1-17a4). As we have said at the beginning, Socrates (or Plato through him) relocates and rethinks the relation between god and men. We will return to this aspect in the following lines.

\section{THE CONFLUENCE OF GLENS AND SOCRATES AS DOORKEEPER}

Let us focus now on the second direct reference present in the dialogue, the one that recalls a bloody battle between Greeks and Trojans as it is described in book 4 of the Iliad. In the Platonic dialogue the reference is located in the next to last section of the dialogue, where -after the long analysis of pleasure that occupies the most part of the dialogue and the short analysis of reason that follows it- the final mixture between both elements is effectively produced in the speech (Philebus, 59d-66d). This mixture represents the best possible life that the dialogue aims to describe from its beginning and this representation is connected with the image of the dwelling place of the good. The production of the mixture, done after a prayer to Dionysus and Hephaestus, ${ }^{28}$ is compared to

\footnotetext{
${ }^{28}$ Dionysus is the god of wine and Hephaestus the god of fire and the forge, therefore, also of technique. The former may represent pleasure, while the latter may represent thought and technique (Klein 1972: 180). Moreover, it is interesting to note that both divinities produce or represent different kinds of mixtures: Dionysus the mixtures concerning wine; and Hephaestus the mixtures necessary for the forge (Robin 1935: 361). The result of each of the mixtures has clearly different objectives: the Dionysian ones are aimed to be used in celebrations or symposia; and in the case of Hephaestus the mixtures are used as tools for construction and also
} 
a mixture made by a wine pourer who must find the right combination and measure between a spring of honey (representing here pleasure) and a spring of water (representing reason or thought) (cf. Philebus, 61b7-c8). This kind of life, understood as a mixture of reason, moderate pleasures and the truth, bring Socrates to stand "at the portico [ (Philebus, 64c1-2). Socractes, as a new Odyssyeus, will be standing at the portico of his desired house without being able to stay there permanently.

Keeping this image of the house in mind, let us see where the direct reference to Homer is to be found. Socrates will be here the wine pourer and will need to decide, and agree with Protarchus, which elements of each spring (the spring or reason and the spring of pleasure) will be accepted in the final mixture. As for the spring of reason, all kinds of sciences are going to be accepted and they will blend without distinction. And this will be so despite of the fact that the section of the dialogue devoted to examine reason and its different kinds established a more or less clear hierarchy of the sciences, from music, medicine or military strategy as more stochastic or less exact sciences to the more exact and pure ones, like mathematics and, above all, dialectics, the science that has access to things "that neither come to be nor perish, but are always in the same way and the same state" (Philebus, 61e2-3). ${ }^{29}$ The description of this situation is made through the Homeric image of the confluence of glens, an image that needs to be put together with the image of Socrates as a doorkeeper overwhelmed by the crown:

Do you want me -he asks Protarchus when he realizes that the blending together seems inevitable- just as if I were a doorkeeper [ $\theta$ vow@ós] who was being pushed and shoved

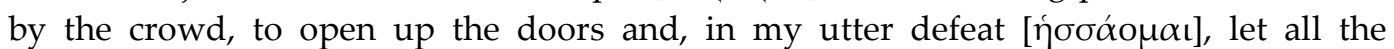
sciences flood in and allow the more deficient to mix with the pure. (Philebus, 62c3-9)

Protarchus adds here that once we have the purest sciences in the mixture, the impure ones cannot harm or affect the composition of the mixture. Exactly after this answer is when Socrates recalls the Homeric image of the confluence of glens: "So I am to let them all flood in into the receptacle of Homers' very

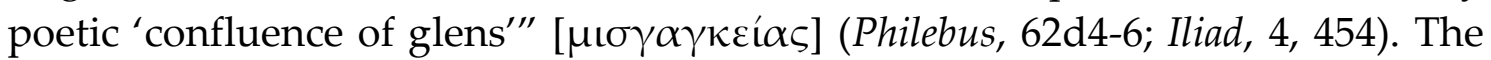
violence of both images is clear but it seems fully irrelevant to Protarchus, who accepts this fact without hesitation. After that, Socrates turns immediately to the

for battle. In fact in the above-mentioned book 18, Homer describes the way Hephaestus forges Achilles' shield and armour, which will serve for his revenge with Hector (Iliad, 18, 465-615).

29 The sciences (specifically the productive sciences) have been classified in 55d-57e. The classification is similar -although not identical- to the one we find in book VI of the Republic (see, for instance, 509d-511e). See for an analysis of the passage in the Philebus Benitez (1999). Protarchus will show himself reluctant to accept that there is a science superior to the art of persuasion that he learned from Gorgias, nevertheless, he concedes that dialectic is the truest of all sciences or arts. Protarchus' reluctance explains part of the tension of the argument. 
analysis of pleasures ${ }^{30}$ and the Homeric reference and its meaning in the action of the dialogue are left behind without any further explanation. As it happened before with the Homeric quote that reveals the hidden mixture between pain and pleasure experienced in tragedies, now Protarchus seems to be again unaware of the consequences and the density of the Platonic use of the Homeric image.

Before going on, let us remind ourselves briefly -as we did with the other reference- of the Homeric scene and its context. As we have said, the quote is from book 4 of the Iliad, which begins with a council of the gods and describes precisely a situation of war, the clash of Greeks and Trojans who are killing and being killed. In the council organized by Zeus, the goddess of youth and cupbearer for the gods Hebe is present, "pouring them nectar as wine". ${ }^{31}$ The council is celebrated because the war has taken an unexpected twist: in the duel for Helen, Menelaus has beaten Paris, but before he could kill him and claim victory, Aphrodite spirited Paris away inside the walls of Troy, bringing him back with Helena. Zeus, to avoid the end of the war and the victory of the Achaeans sends Athena, who orders a Trojan soldier to injury Menelaus and, in doing so, the Trojans break the oath that was taken. This fact will produce the wrath of the Achaeans and especially of Agamemnon: "So, the Trojans have stuck you [Menelaus] down and trampled on the oath sworn. Still the oath and the blood of the lambs shall not be called vain, the unmixed wine poured and the right hands we trusted" (Iliad, 4, 157-160). So despite the agreements and the good words, the oath between the Achaeans and the Trojans has been broken, but Agamemnon believes that the gods will repair this deception somehow, because "Zeus the father shall not be one to give aid to liars" (Iliad, 4, 235). ${ }^{32}$

\footnotetext{
${ }^{30}$ In the case of the spring of pleasure only the most pure ones are going to be allowed in the mixture, because as the dialogue has shown, mixed pleasures (like the ones that are to be experienced in the Homeric tragedies and also in comedies) are often false and unjust and produce in us false expectations, hopes and representations of our own existence; due to their unlimited nature, pleasures cannot enter without distinction in the best mixture, they cannot be part of the best possible life.

${ }^{31}$ It is worth mentioning that Hebe is in Plato's Philebus a relevant and unmentioned divinity represented, indirectly, by Philebus, who's name means "the lover of the youth" or, if you wish, "the lover of Hebe". Hebe was the cupbearer for the gods of Mount Olympus, serving their nectar and ambrosia; in the dialogue the one who acts as cupbearer is Socrates (cf. Philebus, 61c3). Plato is, as usually, rethinking ina very creative way important elements of the tradition.

${ }^{32}$ When Agamemnon sees his injured brother Menelaus, he sends the "blameless physician" Machaon, son of Asklepios. Machaon will be wounded himself and treated by giving him a cup of hot wine sprinkled with grated goat cheese and barley (Iliad, 11, 638). The presence of a physician could have nothing to do with the presence of medicine as a stochastic science in the Philebus but the coincidence is nevertheless worth mentioning. Also military strategy is present immediately after, when Agamemnon inspects the troops before the battle, "he regarded through the ranks of his men and set them in order" (Iliad, 4, 250).
} 
When the troops finally meet in the field, Homer describes the scene and the mentioned quote becomes known:

\begin{abstract}
Now as these advancing came to one place and encountered, they dashed their shields together and their spears, and the strength of armored men in bronze, and the shields massive in the middle clashed against each other, and the sound grew huge of the fighting. There the screaming and the shouts of triumph rose up together of men killing and men killed, and the grounds ran blood. As when rivers in winter spate running down from the mountains throw together at the meeting of streams [ $\mu \iota \gamma \alpha \dot{\alpha} \gamma \kappa \varepsilon\llcorner\alpha \nu]$ the weight of the water out of the great springs behind in the hollow stream-bed, and far away in the mountains the shepherd hears their thunder; such, from the coming together of men, was the shock and the shouting ${ }^{33}$
\end{abstract}

The density of the Homeric image is, again, overwhelming. The first elements that seems to be worth mentioning is the violence of the situation described: the image seems to imply that as it happens in the battlefield (where both sides are killing and being killed), the blending together of all sciences represents its mutual annihilation or, if you wish, it represents the chaos and the disorder. This chaos and disorder are to be found in human life, the place where the mixture takes place. However, in which sense is this chaos to be understood? As the dialogue between Socrates and Protarchus shows, blending all kinds of knowledge means that the divine knowledge about figure, justice or dialectics cannot be detached from human knowledge of figures, justice and dialectics. In a similar way, music (a mimetic and stochastic knowledge far less exact and less precise than arithmetic or dialectics) must be accepted in the mixture provided that without it -Protarchus states- "our life will ever be in any way whatsoever a life" (Philebus, 62c3-4). This blending together is, from the point of view of Protarchus, a condition for Socrates to go back home; they must mix them all, he says, "if in fact any of us is going to find at any time the way home" (Philebus, 62b8-9). Protarchus is here repeating in a subtle way the threat to Socrates that we mentioned before. We as readers could somehow agree with Protarchus' point of view, because there is no happiness without the concrete and human dimension represented here by music or human justice. If we translate this idea into the image of the Platonic Republic, there is no way out of the cave without the way into the cave; the image of the way home and the image of life with which Protarchus reminds the reader seem to be images of the interior of the cave, ${ }^{34}$ but they are as well threats to Socrates. The image of the blending together of all kinds of sciences makes us stay in the interior of the cave and this situation is described by the Platonic art of writing as violent and tragic.

33 Iliad, 4, 446-456. The italics are marking the Platonic reference.

${ }^{34}$ An interior of the cave where, as Benardete says, "perhaps Protarchus believes Gorgianic rhetoric would exercise its power and supplement the knowledge of beings" (Benardete 1993: 231). 
However, is this violent situation due to the mingling together of the sciences or due to the threats that compel Socrates to produce this mingling? Maybe a combination of both elements? We cannot know it with certainty, but it seems clear that Socrates wants to show to Protarchus and to the reader the dangers of mixing all kinds of sciences in the final mixture of which the best possible life consists. This has a somehow metaphorical correspondence with the Homeric scene, where we clearly see that the state of war is reached due to different betrayals, due to the fact that both gods and humans are constantly lying to each other and this is so because both gods and humans are constantly subject to emotions that are inconspicuously mixed and that produce contradictory actions. It is true, in the dialogue dialectic clearly wins because it is presented as the most pure and exact of all sciences (scf. Philebus, 57e-59d), but this is only an apparent victory which is contradicted by the action of the dialogue itself, particularly by Protarchus responses and by the unexpressed content of the conversation. And again, also in the Homeric scene an apparent victory is to be found, a victory that is and is not a victory because Aphrodite appears at the last second and saves Paris, the apparently lover of Helena. The gods and the men of the Homeric scene are the opposite of pure and exact reason, they may even represent the irrationality or the annihilation of reason and this situation is not far away from the one we find in the Platonic dialogue. In both cases, Aphrodite seems to be at the origin of the confrontation, in the dialogue through its identification with the limitlessness of pleasure, in the Homeric poem through the betrayal of the oaths established between men and gods.

All in all, Socrates must accept that the world is an irrational and an inexact one, a chaotic world where exact sciences like dialectics must live together with the inexact ones and, in this sense with rhetoric or sophistry, with the dangers that this fact implies for the dialogue and also for life in the city (and for the life of Socrates himself). ${ }^{35}$ Both in the poem and in the dialogue it seem impossible to live a life of purity, in the first case because of godly and the human disloyalty; in the second one because knowledge of the concrete cannot be detached from knowledge of the general, or because Protarchus is not willing to accept the victory of dialectics over less exact sciences, like music or, if you wish, persuasion or rhetoric.

The image of a life deprived of order implies the disorder in the soul and in the city, and this same image of chaos is the one reproduced by Socrates through the image of the doorkeeper overwhelmed by the crowd, a crowd that

\footnotetext{
35 We must always keep in mind the destiny of the historical Socrates, who was condemned by the city of Athens for corrupting the youth and inventing new gods. His first accusation being based on an identification between Philosophy and Sophistry or rhetoric. In this sense, Protarchus need of mixing together dialectics or Philosophy and rhetoric has a tragic reading, because it leaves Socrates without any possible defence in front of his accusation.
} 
could very well represent the opinion of the masses, of the people who, like Protarchus, don't care much about order in sciences, but rather for the immediate pleasure, an immediate pleasure like the one you get from rhetoric or music. Protarchus sees no harm in this chaos, possibly because he lives in it, he lives a life of pleasure, a life in the limitlessness of pleasures that do not let him understand the dangers of wrongly understanding the relevance of reason for life. Protarchus is happy to know that music will be included in the final mixture, because he enjoys music as he enjoys the Socratic speeches or the discourses of Gorgias. As we have said, the image of chaos and war fades out immediately in the dramatic action of the dialogue maybe because, as Benardete states, "war as the central fact of political life has been disguised through the poet". ${ }^{36}$

In the Homeric imaginary, another element can wake our interest concerning the relevance of the disorder and the confrontation, an element that the Platonic dialogue is omitting for a second time: the presence of Eris, the goddess of chaos, strife and disorder. In the Homeric poem, Eris serves in this occasion to describe the situation of war between the two armies: the Achaeans are depicted as a unified group which "went silently, you would not think all these people with voices kept in their chests were marching; silently, in fear of their commanders" (Iliad, 4, 428-432); whereas the Trojans are presented as a dispersed group of men, talking different languages, "since there was no speech nor language common to all of them but their talk was mixed". ${ }^{37}$ The Achaeans were driven by Ares and Athena, whereas "Terror drove them [the Trojans], and Fear, and Hate ["E@ıs] whose wrath is relentless". ${ }^{38}$ In the scene of the Iliad, Hate ("Eoı $\varsigma$ ) is told to be a little thing in the first instance, but after "grows until she strides on the earth with her head striking heaven" (Iliad, 4, 445). This divinity seems to be responsible for the bitterness and produces more pain in both sides. In Plato's Philebus, eristic is not considered a divinity anymore; whereas dialectics -not being a divinity either- is described, as we have said, as a gift from the gods to men, a gift that is at the origin of any art or technique and also as an image of the proper way to engage in a dialogue. In Plato's Philebus eristic is described as the opposite of dialectics, it means a discourse where the aim is not the truth but the defense of one's own position and the

\footnotetext{
${ }^{36}$ Benardete (1993: 233).

${ }^{37}$ If we observe the Homeric description of the opponents, which in the Platonic dialogue are represented by the more pure and the less pure science, we can see a quite interesting equivalence. In the description of both armies, one is depicted as unified and silent and the other one as disunited and talking different languages. In the dialogue the two armies seem to correspond to the pure and impure sciences; pure sciences deal always with identical unities (as mathematics and dialectics show) and impure ones treat with more complex and dissimilar unities (as in military strategy, for instance).

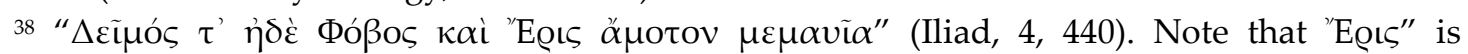
translated by Lattimore as "Hate".
} 
love of victory ( $\phi \iota \lambda$ ovıкı $\alpha$; Philebus, 17a1-5). Proper dialogue is possible if the interlocutors are not seen as rivals or enemies, but as friends working together to achieve a common goal. Achieving this goal is one of Socrates' priorities in the dialogue with Protarchus, who during the conversation seems more interested in the victory of his discourse (or in the defeat of the Socratic one) than in the search for the truth. Again, the Platonic dialogue seems to offer us a way to end the eternal confrontations between men and between men and gods. Nevertheless, as we have seen just before, dialectics seem to be condemned to live together with other less exact sciences and, in this sense, this gift of the gods may be annihilated as the Homeric image of the "confluence of glens" suggests.

Finally, and as a conclusion, let us return to the image of the Socratic journey, the way back home of the hero and the relevance of the choice of life that lies at the background of the dialogue. The Socratic journey in Plato's Philebus is aiming at reaching the dwelling place of the good and the best possible life, a life understood as a mixture of reason, moderate pleasures and the truth. When Socrates finishes the description of this life, he stands, as a new

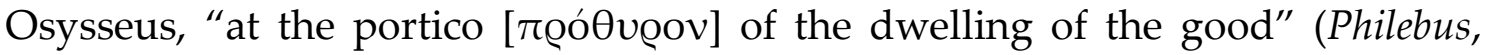
64c1-2). This place is the same that Socrates mentions just before the image of the confluence of glens comes into play, where he compare himself with a

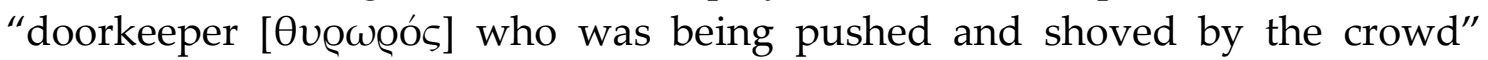
(Philebus, 62c5-6). Socrates, overwhelmed by the crowd, is obliged to let the less exact sciences entering into the mixture of the best possible life and, furthermore, he will not be able to access this, as he will not be able to return home.

This fact, the Socratic impossibility of returning home, means from the perspective of the dialogue, the inaccessibility of the good itself and the necessary distance between human and transcendental order. In this sense we can find in the dialogue a revalorization of the sensible world in front of a pure transcendent and ideal word, the world on the outside of the cave ${ }^{39}$ and, at the same time, a clear statement that we, as human being, are unable to completely reach happiness. The impossibility of returning home has to do, at the same time, with the fact that Protarchus and the young people around him are constantly threatening Socrates saying that he cannot escape and return home before having reached a limit in the explanations (Philebus, 19d-e). ${ }^{40}$ At the very

39 This is the reading of Samuel Scolnicov, who affirms that the problem of the one and the many that is presented in the dialogue implies a treatment of many situation in the sensible world, in the human world of the impure sciences; this is, from his point of view, the sense of the third questions asked in Philebus 15b3-8. Cf. Scolnicov (2010: 333).

${ }^{40} \mathrm{~A}$ threat that will be repeated in $23 \mathrm{~b}$, when Protarchus affirms that due to Socrates argument (an argument where Philebus divinity is definitely dethroned) pleasure has fallen in her fight for victory: "you don't realize -says Protarchus in an unfriendly manner to Socrates- that not one among us would let you go before you have carried the discussion of these questions to its 
end of the dialogue, Protarchus, the youngster who never has enough of Socrates' speeches, is not letting him go because he still has another question to ask (Philebus, 67b). This is how the dialogue finishes, leaving the reader with the indetermination and Socrates without his desired home. In asking him a new question, Protarchus shows his insatiable desire for speeches; his unlimited pleasure has not been removed by the dialogue with the wise Socrates. Protarchus choice is at the end a choice for the pleasures of speech, for an unlimited life with unlimited boundaries that seems to be, overall, a human life. This choice, as the choice of Paris for Aphrodite, seems to be at the very origin of the confrontation that the dialogue represents.

All in all, Socrates seems to be presented in this sense as a new Odysseus on his way back home; both Odysseus and Socrates must take a long journey to go back home, facing difficulties and dangers, and once there, once they are almost at the dwelling of the desired end, they still need to fight and will not be able to access it. The Homeric hero also stands at the portico of his house before entering the palace in Troy, and he will be threatened by the pretenders exactly

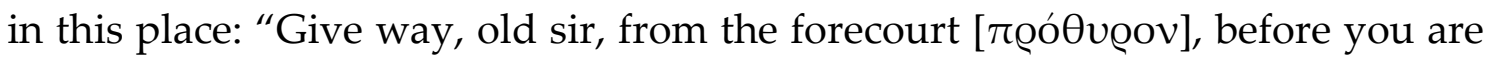
taken and dragged out. Do you see how all of them are giving the signal and telling me to drag you" (Odyssey, 18, 10). Odysseus will be able to protect his house from their enemies, but will not be able to stay there or to enter into it. Odysseus will need to fight and win all of Penelope's pretenders, whereas Socrates will need to engage in a dialogue in order to avoid letting the life of pleasure enter alone in the house of the good. Be it as it may, in both situations the desired goal is not achieved completely. Socrates and Odysseus share a somehow tragic destiny that in the case of Socrates is not based on a prophecy, but has a more philosophic meaning: the inaccessibility of the good itself and the necessary and due distance between human and transcendental or divine order. Socrates reminds nevertheless a hero, a new hero that is able to resist the threats of the young hedonists and try at the same time to orient them toward the proper way of life. He is not living this situation with despair like the Homeric Odysseus, but with a tragi-comical spirit imprinted by the Platonic art of writing.

end" (Philebus, 23b1-4). Afterwards, having described the mixed pleasures and before analyzing the unmixed ones, Socrates states: “Now speak. Are you letting me go, or will you keep me up to midnight? But, I suspect, if I just make a small remark, I'll succeed in winning from you my release" (Philebus, 50d6-8). See Klein (1972: 176). Other threads directed to Socrates from the young Protarchus can be read in 16a6, 19d8-e5, $20 \mathrm{b3}$ and 62b7-9. 


\section{BIBLIOGRAPHY}

BenARDETE, S. (1993), The tragedy and comedy of life. Plato's Philebus, Chocago, University of Chicago Press.

BENITEZ, E. (1999a) “La classification des sciences (Philèbe 55c-59d)”, Dixsaut, M. (ed.), La fêlure du plaisir: études sur le Philèbe de Platon I. commentaires sous la direction de Monique Dixsaut, Paris, Vrin, 337-364.

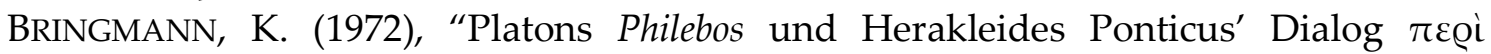

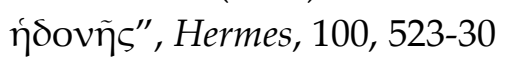

Burnet, J. (1903), Plato. Platonis Opera, Oxford, Oxford University Press. (URL: http://www.perseus.tufts.edu/hopper/collection?collection=Perseus:collection:Gr eco-Roman)

DE la Taille, A. (1999), “Aux Portes du bien (64a7-65a6 et l'interprétation de Gadamer)", Dixsaut, M. (ed.), La fêlure du plaisir: études sur le Philèbe de Platon I. commentaires sous la direction de Monique Dixsaut, Paris, Vrin, 365-383.

DelcomminetTe, S. (2006) Le Philebe de Platon: Introduction a L'Agathologie Platonicienne, Paris, Brill.

Dillon, J. (1999), “Speusippe et le plaisir”, M. Dixsaut, F. Teisserenc (eds.), La Fêlure du Plaisir, Paris. 83-98.

DiLlon, J. (2003), The Heirs of Plato: A Study of the Old Academy (347-274 BC), Oxford, 6776.

DiXSAUT, M. (ed.) (1999), La fêlure du plaisir: études sur le Philèbe de Platon I. commentaires sous la direction de Monique Dixsaut, Paris, Vrin.

FredE, D. (1993), Plato. Philebus, Cambridge, Hackett Publishing Company.

FREDE, D. (2010), "Life and its Limitations: the conception of happiness in the Philebus", Dillon, J. \& Brisson, L. (eds.) Plato's Philebus. Selected papers from the eight Sumposium Platonicum, Sankt Augustin, Academia Verlag, 3-16.

Gosling, J. C. B. (1975), Plato. Philebus, Oxford, Clarendon Press.

Hampton, C. (1990), Pleasure, Knowledge, and Being. An analysis of Plato's Philebus, New York, State University of New York Press.

HAROLD, T. (2008), "The Dyschereis of the Magna Moralia", PLATO, The electronic Journal of the International Plato Society, 8. 1-15.

HOMER. Homeri Opera in five volumes, Oxford, Oxford University Press, 1920.

HOMER. The Odyssey, Cambridge, Harvard University Press; London, William Heinemann, Ltd, 1919.

KLEIN, J. (1972) “About Plato's Philebus”, Interpretation, a journal of political philosophy, 2/3, 157-182.

LABARBE, J. (1987), L'Homère de Platon, Paris, Les Belles Lettres.

LATTIMORE, R., (1977) (trans.), The Odyssey of Homer, New York, Hagerstown, San Francisco, London, Harper \& Row.

LATTIMORE, R., (1975) (trans.), The Iliad of Homer, Chicago, University of Chicago Press.

LISI, F. (2010), "Ley, placer e intelecto en el Filebo", Dillon, J. \& Brisson, L. (eds.) Plato's Philebus. Selected papers from the eight Sumposium Platonicum. Sankt Augustin, Academia Verlag, 178-187. 
PlaniNC, Z. (1997) “The Significance of Plato's Timaeus and Critias in Eric Voegelin's Philosophy," Second International Conference on the Work of Eric Voegelin (1997)

Planinc, Z. (2003), Plato through Homer: Poetry and Philosophy in the Cosmological Dialogues, University of Missouri Press

PlaniNC, Z. (2004) “Ascending with Socrates: Plato's Use of Homeric Imagery in the Symposium", Interpretation 31/3, 325-350

PlaniNC, Z. (2007), “Equivalences of Experience and Symbolization in Plato and Homer", Annual Meeting Papers. Chicago 2007. [Catalan translation: Planinc, Z. (2008) "Equivalències d'experiència i simbolització en Plató i Homer", Butlletí Platònic V, Anuari de la Societat Catalana de Filosofia XIX, Barcelona, 133-139]

ROBIN, L. (1950), Plato, Oeuvres complètes, vol. II. Paris, Gallimard.

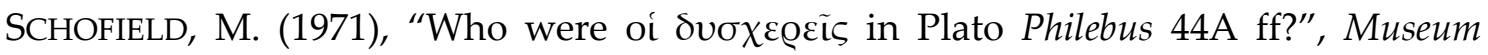
Helveticum, 28, 2-20.

Voegelin, E. (2000) Order and History, vol. III. Plato and Aristotle. The collected works of Eric Voegelin 16, Columbia \& London, University of Missouri Press.

Wersinger, A.-G. (2010), "L'apeiron et les relatifs dans le Philèbe", Dillon, J. \& Brisson, L. (eds.) Plato's Philebus. Selected papers from the eight Sumposium Platonicum, Sankt Augustin, Academia Verlag, 348-354. 